\title{
Elegía inconclusa y otros poemas
}

Nunca conocí personalmente a Uwe Frish. La primera vez que oi hablar de él fue a propósito de sus traducciones de las Elegías de Duino que había publicado en la Revista de Bellas Artes(nueva época, julio-agosto de 1975). Posteriormente hablé con él un par de veces, aunque sólo por teléfono. Yo trabajaba entonces en la redacción de la ahora desafortunadamente desaparecida revista Diálogos, en la que él colaboró con un ensayo sobre Julián Carrillo. En ese tiempo - me dijo- estaba traduciendo una elegía inconclusa de Rilke, de la que Jaime Ferreiro Alemparte había publicado una versión incompleta porque el mismo poeta consideraba que las tres estrofas finales estaban " parcial o totalmente en estado fragmentario". La prometió para Diálogos, por lo que yo quedé en llamarle por teléfono el mes siguiente (era octubre de 1984). Y con mucho gusto lo hubiera hecho si el destino de Diálogos que ahora ya todos conocemos y lamentamos no hubiera comenzadoa fraguarse entonces y yo, por supuesto, no hubiera tenido que dejar la redacción de la revista. Más tarde me enteré que Uwe Frish habia muerto repentinamente el mismo mes en que yo debi haberle llamado. Sin embargo, parece que la vida le dió tiempo para terminar la traducción de la "Elegía inconclusa". ${ }^{1}$ Yo, por mi parte, cumplo también al publicarla junto con otros poemas de Rilke, también traducidos por él.

Para mi Uwe Frish es ante todo el traductor de las Elegías de Duino al españo. He leído y releído muchas veces esta versión de las Elegías y también las de aquéllos que lo precedieron en la empresa y las de los que vinieron después de él, ${ }^{2}$ pero siempre que recuerdo a Rilke en español también recuerdo a Uwe Frish.

Rilke escribió sus Elegías de Duino entre enero 1912 y febrero de 1922. Así, se puede decir que la poesía más honda y entrañable de nuestro siglo nació en medio de las ruinas de la Primera Guerra Mundial y la alharaca vanguardista. En medio, pero al mismo tiempo ajena a una y a otra. Los poemas que leeremos a continuación son una muestra de lo que Rilke escribió y sintió y entrevió mientras creaba la parte más importante de su obra. ${ }^{3}$

G. T.

${ }^{1}$ Aquí quiero agradecer a la viuda de Uwe Frish que nos haya proporcionado tan amablemente las traducciones que aparecen en este número de Estudios.

${ }^{2}$ Para una bibliografia más detallada de Rilke en español, véase el libro Rainer María Rilke de Hans Egon Holthusen, trad. de Jaime Ferreiro Alemparte, Madrid, Alianza Editorial, 1968, 273 pp. Cito sólo a los tradutores de las Elegias de Duino que he leído: Horacio Quiñones (1966), Jaime Ferreiro Alemparte (1968), E.M.S. Danero (1973) y José María Valverde (1980).

${ }^{3}$ Aparte del poema "Mientras atrapes únicamente aquello" y la ya citada Elegía los demás poemas, hasta donde sé, no han sido traducidos al español. 